\title{
Chemical Composition, Enantiomeric Distribution, and Antifungal Activity of the Oleoresin Essential Oil of Protium amazonicum from Ecuador
}

\author{
Prabodh Satyal ${ }^{1,2}$, Chelsea N. Powers ${ }^{1}$, Rafael Parducci V. ${ }^{3}$, Robert L. McFeeters ${ }^{1}$ \\ and William N. Setzer $1,2, *$ \\ 1 Department of Chemistry, University of Alabama in Huntsville, Huntsville, AL 35899, USA; \\ prabodhsatyal@gmail.com (P.S.); cnp0007@uah.edu (C.N.P.); robert.mcfeeters@uah.edu (R.L.M.) \\ 2 Aromatic Plant Research Center, 615 St. George Square Court, Suite 300, Winston-Salem, NC 27103, USA \\ 3 Saintoil S.A., Magnolias 57, Quito 17-22-20108, Pinchachas, Ecuador; Saintoil@aol.com \\ * Correspondence: wsetzer@chemistry.uah.edu; Tel.: +1-256-824-6519
}

Academic Editor: Helen D. Skaltsa

Received: 5 August 2017; Accepted: 21 September 2017; Published: 23 September 2017

\begin{abstract}
Background: Protium species (Burseraceae) have been used in the treatment of various diseases and conditions such as ulcers and wounds. Methods: The essential oil from the oleoresin of Protium amazonicum was obtained by hydrodistillation and analyzed by GC-MS, GC-FID, and chiral GC-MS. P. amazonicum oleoresin oil was screened for antifungal activity against Candida albicans, Aspergillus niger, and Cryptococcus neoformans. Results: A total of 54 components representing 99.6\% of the composition were identified in the oil. The essential oil was dominated by $\delta$-3-carene $(47.9 \%)$ with lesser quantities of other monoterpenoids $\alpha$-pinene (4.0\%), $p$-cymene $(4.1 \%)$, limonene $(5.1 \%)$, $\alpha$-terpineol (5.5\%) and $p$-cymen-8-ol (4.8\%). Chiral GC-MS revealed most of the monoterpenoids to have a majority of levo enantiomers present with the exceptions of limonene and $\alpha$-terpineol, which showed a dextro majority. P. amazonicum oleoresin oil showed promising activity against Cryptococcus neoformans, with MIC $=156 \mu \mathrm{g} / \mathrm{mL}$. Conclusions: This account is the first reporting of both the chemical composition and enantiomeric distribution of the oleoresin essential oil of $P$. amazonicum from Ecuador. The oil was dominated by (-)- $\delta-3$-carene, and this compound, along with other monoterpenoids, likely accounts for the observed antifungal activity of the oil.
\end{abstract}

Keywords: essential oil composition; Protium amazonicum; Burseraceae; copal; breu; $\delta$-3-carene; chiral gas chromatography; antifungal activity

\section{Introduction}

Protium amazonicum (Cuatrec.) Daly belongs to the Burseraceae, which is comprised of 640 species representing 18 genera throughout the world, mainly distributed in the Neotropics and North Africa [1]. The main characteristic of the Burseraceae is the exuding aromatic resin [2,3], which is known as "copal" in Spanish [4] and "breu" in Portuguese [5]. Protium spp. have been used in the treatment of various diseases and conditions such as ulcers and wounds, to treat headaches, toothaches, and rheumatism [2], because of their anti-inflammatory [6,7], antinociceptive [8,9], antineoplastic [10], and gastroprotective [11,12] properties. The Yanomami people of Brazil use the resin of P. fimbriatum to treat respiratory infections [13]. Protium oleoresins have been characterized in terms of color, age, odor, as well as volatile and non-volatile chemical characteristics (Table 1) [5,14]. Because of the importance of Protium oleoresins in traditional medicine and because no previous work had been carried out on P. amazonicum, we wished to chemically characterize the oleoresin essential oil of P. amazonicum; this information should add to our understanding of Protium oleoresin chemistry. 
Table 1. A brief review of Protium oleoresin traditional medicinal uses, biological properties, and essential oil compositions. ${ }^{\text {a }}$

\begin{tabular}{|c|c|c|c|}
\hline Species & $\begin{array}{l}\text { Traditional Medicinal Uses and/or } \\
\text { Biological Activities }\end{array}$ & Major Components & Ref. \\
\hline $\begin{array}{l}\text { P. altsonii } \\
\text { (sucuruba) }\end{array}$ & & $\begin{array}{l}p \text {-cymene }(16.3 \%), \gamma \text {-cadinene }(9.5 \%), \\
\gamma \text {-gurjunene }(5.2 \%)\end{array}$ & [15] \\
\hline P. bahianum & $\begin{array}{l}\text { Treatment of wounds, ulcers, } \\
\text { inflammation, and as an insect repellent }\end{array}$ & $\begin{array}{l}\text { Fresh resin: } p \text {-cymene }(18.3 \%), \alpha \text {-phellandrene } \\
(14.0 \%), \text { tricyclene }(11.4 \%), \beta \text {-phellandrene }(9.1 \%) \text {, } \\
\beta \text {-pinene }(6.6 \%)\end{array}$ & [16] \\
\hline P. bahianum & Acaricidal activity (Tetranychus urticae) & Aged resin: $(E)-\beta$-santalol acetate $(83.1 \%)$ & [16] \\
\hline P. decandrum & & $\begin{array}{l}\alpha \text {-trans-bergamotene }(47.7 \%), \alpha \text {-cis-bergamotene } \\
(6.5 \%), \beta \text {-caryophyllene }(5.9 \%) \text {, ar-curcumene }(5.2 \%)\end{array}$ & [17] \\
\hline $\begin{array}{l}\text { P. decandrum } \\
\text { (black breu) }\end{array}$ & & $\begin{array}{l}\delta \text {-3-carene }+ \text { iso-sylvestrene }(40.9 \%), p \text {-cymene } \\
(13.4 \%), \text { limonene }+\beta \text {-phellandrene }(20.3 \%)\end{array}$ & [15] \\
\hline $\begin{array}{l}\text { P. decandrum } \\
\text { (white breu) }\end{array}$ & $\begin{array}{l}\text { Burning and inhaling smoke to treat } \\
\text { headache }\end{array}$ & $\begin{array}{l}p \text {-cymene }(32.4 \%), \alpha \text {-phellandrene }(21.0 \%), \alpha \text {-pinene } \\
(19.0 \%), \text { limonene }+\beta \text {-phellandrene }(12.0 \%)\end{array}$ & [15] \\
\hline P. heptaphyllum & $\begin{array}{l}\text { Antimicrobial (Candida albicans, } \\
\text { MIC }=1.25 \mu \mathrm{g} / \mathrm{mL} ; \text { Staphylococcus } \\
\text { aureus, } \mathrm{MIC}=2.5 \mu \mathrm{g} / \mathrm{mL} \text { ) }\end{array}$ & $\begin{array}{l}\alpha \text {-pinene }(10.5 \%), \alpha \text {-phellandrene }(16.7 \%), p \text {-cymene } \\
(6.0 \%) \text {, limonene }(16.9 \%) \text {, terpinolene }(28.5 \%)\end{array}$ & [18] \\
\hline P. heptaphyllum & Antinociceptive (mouse model) & $\begin{array}{l}\text { 1,8-cineole }(58.7 \%), \alpha \text {-terpinene }(13.7 \%) \\
\alpha \text {-phellandrene }(10.4 \%), \gamma \text {-terpineol }(7.7 \%)\end{array}$ & [9] \\
\hline P. heptaphyllum & Anti-inflammatory (rat model) & $\begin{array}{l}\text { limonene }(50.0 \%),(E) \text { - } \beta \text {-ocimene }(11.8 \%), 1,8 \text {-cineole } \\
(10.9 \%), p \text {-cymene }(10.8 \%), \alpha \text {-phellandrene }(10.0 \%)\end{array}$ & [7] \\
\hline P. heptaphyllum & Anti-genotoxic activity & $\begin{array}{l}\text { terpinolene }(32.7-37.8 \%), p \text {-cymene }(7.9-38.1 \%) \text {, } \\
\text { limonene }(0-2 \%), \delta \text {-3-carene }(0-15.0 \%), \alpha \text {-thujene } \\
(0-1.1 \%), p \text {-cymen- } 8 \text {-ol }(2.5-10.1 \%)\end{array}$ & [19] \\
\hline P. heptaphyllum & & $\begin{array}{l}\text { Fresh resin: terpinolene }(28.2-69.7 \%), p \text {-cymene } \\
(4.3-23.3 \%), \alpha \text {-pinene }(3.6-14.6 \%), \alpha \text {-terpinene } \\
(3.1-10.4 \%) \text {, limonene }(6.4-10.1 \%), p \text {-cymen-8-ol } \\
(2.7-9.8 \%)\end{array}$ & [20] \\
\hline P. heptaphyllum & & $\begin{array}{l}\text { Aged resin: } p \text {-cymene }(18.7-43.0 \%), \text { terpinolene } \\
(8.8-21.6 \%), \alpha \text {-pinene }(3.5-17.8 \%), \alpha \text {-limonene } \\
(5.8-1.6 \%), p \text {-cymen-8-ol }(8.2-31.8 \%)\end{array}$ & [20] \\
\hline P. heptaphyllum & & $\begin{array}{l}\text { Fresh resin: myrcene (35.0\%), } \alpha \text {-pinene }(27.0 \%), \\
\text { sabinene }(11.0 \%), \beta \text {-caryophyllene }(7.2 \%)\end{array}$ & [10] \\
\hline P. heptaphyllum & $\begin{array}{l}\text { Cytotoxic on SP2/0 (murine } \\
\text { plasmocytoma) and J774 (murine } \\
\text { monocytic macrophage) cell lines }\end{array}$ & $\begin{array}{l}\text { Freshly tapped resin: terpinolene }(28.0 \%), p \text {-cymene } \\
(16.0 \%), \alpha \text {-pinene }(8.7 \%), \alpha \text {-terpinene }(6.6 \%) \\
\text { limonene }(5.5 \%), p \text {-cymen-8-ol }(5.6 \%)\end{array}$ & [10] \\
\hline P. heptaphyllum & $\begin{array}{l}\text { Antibacterial (Streptococcus mutans, MIC } \\
0.13 \mu \mathrm{g} / \mathrm{mL} \text { ) }\end{array}$ & $\begin{array}{l}\text { tricyclene }(11.1 \%), p \text {-cymene }(26.7 \%) \text {, terpinolene } \\
(35.8 \%), p \text {-cymen- } 8 \text {-ol }(10.1 \%)\end{array}$ & [21] \\
\hline P. heptaphyllum & $\begin{array}{l}\text { Vasorelaxant (rat upper mesenteric } \\
\text { artery ring, } \mathrm{IC}_{50} 316 \mu \mathrm{g} / \mathrm{mL} \text { ) }\end{array}$ & $\begin{array}{l}\delta \text {-3-carene }(5.1 \%), p \text {-cymene }(17.0 \%), \text { limonene } \\
(34.5 \%), 1,8 \text {-cineole }(20.6 \%), \alpha \text {-terpineol }(9.8 \%)\end{array}$ & [22] \\
\hline P. heptaphyllum & & $\begin{array}{l}\alpha \text {-phellandrene }(7.0 \%), p \text {-cymene }(26.9 \%), \text { limonene } \\
(28.9 \%), \alpha \text {-terpineol }(18.4 \%)\end{array}$ & [22] \\
\hline P. heptaphyllum & & $\begin{array}{l}\text { Fresh resin: } \alpha \text {-terpinene }(18.0 \%), p \text {-cymene }(36.0 \%) \text {, } \\
\gamma \text {-terpinene }(12.0 \%)\end{array}$ & [23] \\
\hline P. heptaphyllum & & $\begin{array}{l}\text { Aged resin: } p \text {-cymene }(11.0 \%) \text {, terpinolene }(15.0 \%) \\
p \text {-cymenene }(5.3 \%), p \text {-cymen- } 8 \text {-ol }(11.0 \%) \\
\text { dillapiole }(16.0 \%)\end{array}$ & [23] \\
\hline P. heptaphyllum & & $\begin{array}{l}\text { Fresh resin: } \alpha \text {-pinene }(10.5 \%), \alpha \text {-phellandrene } \\
(16.7 \%), p \text {-cymene }(6.0 \%), \text { limonene }(16.9 \%) \\
\text { terpinolene }(28.5 \%)\end{array}$ & [24] \\
\hline $\begin{array}{l}\text { P. heptaphyllum } \\
\text { (black breu) }\end{array}$ & $\begin{array}{l}\text { Treatment of headaches (inhalation); } \\
\text { treat pain and inflammation (plasters) }\end{array}$ & & [25] \\
\hline $\begin{array}{l}\text { P. heptaphyllum } \\
\text { (black breu) }\end{array}$ & & $\delta$-3-carene + iso-sylvestrene $(79.5 \%)$ & [15] \\
\hline $\begin{array}{l}\text { P. heptaphyllum } \\
\text { (black breu) }\end{array}$ & & $\begin{array}{l}\delta \text {-3-carene }+ \text { iso-sylvestrene }(56.4 \%), p \text {-cymene } \\
(14.0 \%), \text { limonene }+\beta \text {-phellandrene }(6.8 \%)\end{array}$ & [15] \\
\hline $\begin{array}{l}\text { P. heptaphyllum } \\
\text { (black breu) }\end{array}$ & & $\begin{array}{l}p \text {-cymene }(33.0 \%), \delta \text {-3-carene }+ \text { iso-sylvestrene } \\
(14.7 \%)\end{array}$ & [15] \\
\hline
\end{tabular}


Table 1. Cont.

\begin{tabular}{|c|c|c|c|}
\hline Species & $\begin{array}{l}\text { Traditional Medicinal Uses and/or } \\
\text { Biological Activities }\end{array}$ & Major Components & Ref. \\
\hline $\begin{array}{l}\text { P. heptaphyllum } \\
\text { (breuzinho) }\end{array}$ & & $\begin{array}{l}\delta \text {-3-carene + iso-sylvestrene }(69.0 \%), p \text {-cymene }(6.4 \%) \\
\text { limonene }+\beta \text {-phellandrene }(5.7 \%)\end{array}$ & [15] \\
\hline $\begin{array}{l}\text { P. heptaphyllum } \\
\text { subsp. } \\
\text { heptaphyllum }\end{array}$ & & $\begin{array}{l}p \text {-cymene }(39.9 \%), n \text {-tetradecane }(13.4 \%) \\
\text { dihydro-4-carene }(11.7 \%), \alpha \text {-phellandrene }(7.4 \%)\end{array}$ & [26] \\
\hline $\begin{array}{l}\text { P. heptaphyllum } \\
\text { subsp. ulei }\end{array}$ & & $\begin{array}{l}\text { terpinolene }(42.3 \%) \text {, p-cymen-8-ol }(13.6 \%) \text {, } \\
\text { limonene }(11.9 \%)\end{array}$ & [26] \\
\hline P. icicariba & & $\begin{array}{l}\alpha \text {-pinene }(5.6-7.7 \%), p \text {-cymene }(20-40 \%), \text { limonene } \\
(5.8-8.0 \%), \alpha \text {-terpinolene }(5.8-31 \%), p \text {-cymen-8-ol } \\
(10-26 \%)\end{array}$ & [27] \\
\hline P. neglectum & $\begin{array}{l}\text { Traditional remedy for inflammations, } \\
\text { as an inhalant to clear respiratory and } \\
\text { bronchial passages, wound healing. } \\
\text { Antibacterial, disk diffusion assay } \\
\text { (Bacillus subtilis, Staphylococcus aureus) }\end{array}$ & $\begin{array}{l}\text { Fresh resin: } p \text {-cymene }(5.2 \%) \text {, durenol }(15.6 \%) \text {, } \\
\alpha \text {-terpineol }(6.9 \%) \text {, piperitenone }(25.4 \%) \text {, thymol } \\
(17.5 \%) \text {, methyl eugenol }(9.2 \%)\end{array}$ & [28] \\
\hline $\begin{array}{l}\text { P. occultum } \\
\text { (white breu) }\end{array}$ & $\begin{array}{l}\text { burning and inhaling smoke to } \\
\text { treat headache }\end{array}$ & $\begin{array}{l}p \text {-cymene }(10.4 \%), \text { limonene }+\beta \text {-phellandrene } \\
(41.1 \%), \alpha \text {-terpineol }(30.9 \%), \alpha \text {-pinene }(8.0 \%)\end{array}$ & [15] \\
\hline $\begin{array}{l}\text { P. cf. opacum } \\
\text { (surucuba) }\end{array}$ & & $\begin{array}{l}p \text {-cymene }(6.6 \%), \alpha \text {-neo-clovene }(5.3 \%) \\
\alpha \text {-neo-callitropsene }(7.3 \%), \gamma \text {-cadinene }(14.4 \%)\end{array}$ & [15] \\
\hline $\begin{array}{l}\text { P. strumosum } \\
\text { (white breu) }\end{array}$ & $\begin{array}{l}\text { burning and inhaling smoke to } \\
\text { treat headahce }\end{array}$ & $\begin{array}{l}\alpha \text {-pinene }(57.7 \%), \beta \text {-pinene }(9.3 \%), p \text {-cymene }(9.2 \%) \\
\text { limonene }+\beta \text {-phellandrene }(10.8 \%)\end{array}$ & [15] \\
\hline
\end{tabular}

\section{Materials and Methods}

\subsection{Essential Oil}

The oleoresin (relatively fresh, yellow, with a terpenic odor) of P. amazonicum was collected from Quito, Ecuador $\left(0^{\circ} 14^{\prime} 0^{\prime \prime} \mathrm{S}, 78^{\circ} 31^{\prime} 0^{\prime \prime} \mathrm{W}, 3000 \mathrm{~m}\right.$ above sea level). The tree was identified by Rafael Parducci, and a voucher specimen has been deposited in Saintoil S.A. The essential oil was obtained by hydrodistillation using a Clevenger apparatus as previously described [29] to give the essential oil.

\subsection{Gas Chromatography-Mass Spectrometry (GC-MS)}

The oleoresin essential oil of P. amazonicum was analyzed by GC-MS using a Shimadzu GC-MS-QP2010 Ultra (Shimadzu Corp., Columbia, MD, USA) operated in the electron impact (EI) mode (electron energy $=70 \mathrm{eV}$ ), with a scan range of 40-400 atomic mass units (amu), a scan rate of 3.0 scans/s, and the GC-MS Solution software (Shimadzu GC-MS-QP2010 Ultra, Columbia, MD, USA). The GC column was ZB-5MS fused silica capillary column (Phenomenex Inc., Torrance, CA, USA) $(30 \mathrm{~mL} \times 0.25 \mathrm{~mm}$ ID) with a (5\% phenyl)-polymethylsiloxane stationary phase with a film thickness of $0.25 \mu \mathrm{m}$. The carrier gas was helium with a column head pressure of $551.6 \mathrm{kPa}$ and flow rate of $1.37 \mathrm{~mL} / \mathrm{min}$. The injector temperature was $250{ }^{\circ} \mathrm{C}$, and the ion source temperature was $200{ }^{\circ} \mathrm{C}$. The GC oven temperature program was programmed for $50{ }^{\circ} \mathrm{C}$ initial temperature, the temperature increased at a rate of $2{ }^{\circ} \mathrm{C} / \mathrm{min}$ to $260^{\circ} \mathrm{C}$. A $5 \%$ w/v solution of the sample in $\mathrm{CH}_{2} \mathrm{Cl}_{2}$ was prepared and $0.1 \mu \mathrm{L}$ was injected with a splitting mode (30:1). Identification of the oil components was based on their retention indices determined by reference to a homologous series of $n$-alkanes, and by comparison of their mass spectral fragmentation patterns with those reported in the literature [30], and stored in the MS library.

\subsection{Gas Chromatography_Flame Ionization Detection}

The gas chromatograph was a Shimadzu GC 2010 (Shimadzu Corp., Columbia, MD, USA) equipped with a flame ionization detector, a split/splitless injector, and autosampler AOC-20i 
(Shimadzu Corp., Columbia, MD, USA). The capillary column was a ZB-5MS (Phenomenex Inc., Torrance, CA, USA) with a film thickness of $0.25 \mu \mathrm{m}$. The column temperature was programmed, $50-250{ }^{\circ} \mathrm{C}$ at $2{ }^{\circ} \mathrm{C} / \mathrm{min}$, the injector temperature was $250{ }^{\circ} \mathrm{C}$, the detector temperature was $280{ }^{\circ} \mathrm{C}$, the carrier gas was nitrogen, and the flow rate was maintained at $1.0 \mathrm{~mL} / \mathrm{min}$. Injection mode split with a split ratio of 1:100. The injected volume was $0.3 \mu \mathrm{L}$ of diluted oil $\left(1: 10 v / v\right.$ with $\left.\mathrm{CH}_{2} \mathrm{Cl}_{2}\right)$. The percent composition of the oleoresin essential oil was calculated from raw peak areas without standardization.

\subsection{Chiral Gas Chromatography-Mass Spectrometry}

Chiral analysis of the P. amazonicum oil was performed on a Shimadzu GCMS-QP2010S (Shimadzu Corp., Columbia, MD, USA) operated in the EI mode (electron energy $=70 \mathrm{eV}$ ), scan range $=40-400 \mathrm{amu}$, scan rate $=3.0$ scans $/ \mathrm{s}$. GC equipped with a Restek B-Dex 325 capillary column $(30 \mathrm{~m} \times 0.25 \mathrm{~mm}$ ID $\times 0.25 \mu \mathrm{m}$ film) (Restek Corp., Bellefonte, PA, USA). Oven temperature was started at $50{ }^{\circ} \mathrm{C}$, and then gradually raised to $120^{\circ} \mathrm{C}$ at $1.5^{\circ} \mathrm{C} / \mathrm{min}$. The oven was then raised to $200^{\circ} \mathrm{C}$ at $2{ }^{\circ} \mathrm{C} / \mathrm{min}$ and held for $5 \mathrm{~min}$. Helium was the carrier gas and the flow rate was maintained at $1.8 \mathrm{~mL} / \mathrm{min}$. The sample was diluted $3 \% w / v$ with $\mathrm{CH}_{2} \mathrm{Cl}_{2}$ and then a $0.1 \mu \mathrm{L}$ sample was injected in a split mode with a split ratio of 1:45. The enantiomers of each monoterpene were identified by comparison of retention times to authentic samples obtained from Sigma-Aldrich (Milwaukee, WI, USA).

\subsection{Antifungal Screening}

The broth microdilution method was performed to determine antifungal activity as previously reported [31,32]. Briefly, cultures of Candida albicans (ATCC 18804) and Cryptococcus neoformans var. neoformans (ATCC 24067) were initially grown on potato dextrose agar (PDA) plates for $72 \mathrm{~h}$ at $37^{\circ} \mathrm{C}$. A single colony was used to inoculate approximately $5 \mathrm{~mL}$ of potato dextrose broth (PDB) which was subsequently grown for an additional $24 \mathrm{~h}$ at $37^{\circ} \mathrm{C}$. Aspergillus niger (ATCC 16888) cultures were grown on PDA plates for 5 days at room temperature (RT, $22^{\circ} \mathrm{C}$ ). A. niger conidia were collected, placed in PDB, and filtered through sterile cheesecloth into fresh PDB. The absorbance of the fresh solution was read at $625 \mathrm{~nm}$ and adjusted accordingly with PDB to an absorbance of 0.15 . Minimum inhibitory concentrations (MICs) were determined in triplicate using 96-well plates. C. albicans and C. neoformans were diluted in 3-(N-morpholino)propanesulfonic acid (MOPS) buffered Roswell Park Memorial Institute (RPMI) medium to 2000 cells $/ \mathrm{mL}$ whereas $A$. niger was diluted with PDB to an $\mathrm{OD}_{625}$ of 0.15 . Initially, $50 \mu \mathrm{L}$ of MOPS buffered RPMI was added to each well of the plate. In the first row, $50 \mu \mathrm{L}$ of essential oil was added and mixed well, then $50 \mu \mathrm{L}$ of this mixture was removed and then added to the medium in the next row. This serial dilution process was repeated for each row of the plate, with the removed volume from the last row being discarded. To each well was added $50 \mu \mathrm{L}$ of cells to achieve a final volume of $100 \mu \mathrm{L}$. C. albicans and C. neoformans were incubated at $37^{\circ} \mathrm{C}$ for $48 \mathrm{~h}$. The $A$. niger plates were incubated at RT for 6 days. The MIC was determined from turbidity or growth on the plates in comparison to positive and negative controls. In order to verify the results, MIC determinations were carried out in nine replicates. A combination of Cyprodinil and Fludioxonil served as the positive control with MOPS buffered RPMI serving as the negative control.

\section{Results and Discussion}

\subsection{Chemical Composition}

The clear pale yellow oleoresin essential oil from P. amazonicum was obtained in $0.3 \%$ yield and analyzed by GC-MS and GC-FID. From a total of 56 peaks, 99.6\% of the compounds were identified in the oil (Table 2). The major components of the resin oil were identified as $\delta$-3-carene $(47.9 \%)$, $\alpha$-pinene $(4.0 \%), p$-cymene $(4.1 \%)$, limonene (5.1\%), $\alpha$-terpineol $(5.5 \%)$ and $p$-cymen- 8 -ol $(4.8 \%)$ (see Figure 1). $\delta$-3-Carene has been reported as a major component in several Protium spp. oleoresin essential oils, including P. decandrum and P. heptaphyllum [15]; however, in most oleoresin essential oils from Protium, $\delta$-3-carene is a minor component or unobserved (see Table 1). Protium oleoresin 
oils show wide variation in chemical composition, depending on species as well as age and color of the resin (Table 1). The age of an oleoresin has a distinct effect on the chemical composition. Some monoterpenes have been found to undergo oxidation upon exposure to atmospheric oxygen [33-35], including oleoresin monoterpenoids [20]. In addition, fresh oleoresin from the same species shows wide variation in chemical composition. Thus, for example, the essential oil from fresh oleoresin of P. heptaphyllum collected from the Restinga of Carapebus, Rio de Janeiro state, Brazil, had myrcene $(35.0 \%)$ and $\alpha$-pinene $(27.0 \%)$ as the major components [10]; the fresh resin oil from Reserva da Campina, Amazonas, Brazil, was rich in $p$-cymene $(36.0 \%), \alpha$-terpinene $(18.0 \%)$, and $\gamma$-terpinene $(12.0 \%)$ [23]; and the fresh resin oil from Crato, Ceara, Brazil was dominated by terpinolene (28.5\%), $\alpha$-phellandrene (16.7\%), and limonene (16.9\%) [24]. The oleoresin in this present work is a relatively fresh resin, reflected in the high concentration of $\delta$-3-carene.

Table 2. Chemical composition of the oleoresin essential oil of Protium amazonicum from Ecuador.

\begin{tabular}{|c|c|c|c|}
\hline $\mathrm{RI}^{\mathrm{calc}}$ & RI $^{\text {lit }}$ & Compound & $\%$ \\
\hline 779 & 780 & Toluene & 0.2 \\
\hline 925 & 930 & $\alpha$-Thujene & 0.7 \\
\hline 932 & 939 & $\alpha$-Pinene & 4.0 \\
\hline 947 & 952 & $\alpha$-Fenchene & 0.2 \\
\hline 949 & 954 & Camphene & 0.1 \\
\hline 970 & 972 & 3,7,7-Trimethyl-1,3,5-cycloheptatriene & 1.4 \\
\hline 972 & 975 & Sabinene & 0.1 \\
\hline 977 & 979 & $\beta$-Pinene & 1.0 \\
\hline 1000 & 1002 & $\delta$-2-Carene & 0.1 \\
\hline 1007 & 1002 & $\alpha$-Phellandrene & 0.5 \\
\hline 1010 & 1011 & $\delta$-3-Carene & 47.9 \\
\hline 1017 & 1017 & $\alpha$-Terpinene & 0.4 \\
\hline 1019 & 1026 & $o$-Cymene & 0.3 \\
\hline 1024 & 1024 & $p$-Cymene & 4.1 \\
\hline 1029 & 1029 & Limonene & 5.1 \\
\hline 1030 & 1029 & $\beta$-Phellandrene & 0.4 \\
\hline 1032 & 1031 & 1,8-Cineole & 0.7 \\
\hline 1057 & 1059 & $\gamma$-Terpinene & 0.5 \\
\hline 1072 & 1072 & Pinol & 0.2 \\
\hline 1080 & 1085 & m-Cymenene & 1.8 \\
\hline 1085 & 1088 & Terpinolene & 0.7 \\
\hline 1090 & 1091 & p-Cymenene & 3.2 \\
\hline 1095 & 1099 & $\alpha$-Pinene oxide & 0.1 \\
\hline 1141 & 1139 & trans-Pinocarveol & 0.1 \\
\hline 1142 & - & 2-Isobutylnorbornane & 0.7 \\
\hline 1147 & 1146 & Camphor & 0.3 \\
\hline 1149 & 1147 & trans-Dihydro- $\alpha$-terpineol & 0.5 \\
\hline 1153 & 1150 & Eucarvone & 0.3 \\
\hline 1162 & 1170 & $\alpha$-Phellandren-8-ol & 1.9 \\
\hline 1170 & 1160 & iso-Borneol & 0.3 \\
\hline 1171 & - & $\beta$-Phellandren-8-ol & 0.9 \\
\hline 1174 & 1169 & Borneol & 0.6 \\
\hline 1180 & 1179 & m-Cymen-8-ol & 4.8 \\
\hline 1183 & - & $p$-Isobutyltoluene & 0.3 \\
\hline 1184 & 1182 & $p$-Methylacetophenone & 0.1 \\
\hline 1186 & 1182 & $p$-Cymen-8-ol & 1.7 \\
\hline 1188 & - & (Z)- $\beta$-Ocimenol & 0.2 \\
\hline 1195 & 1188 & $\alpha$-Terpineol & 5.5 \\
\hline 1207 & 1205 & Verbenone & 0.2 \\
\hline 1210 & 1217 & 4-Methyleneisophorone & 3.0 \\
\hline 1220 & - & 2-Carone & 0.9 \\
\hline 1240 & 1238 & (E)-Ocimenone & 0.2 \\
\hline 1242 & 1241 & Cuminal & 0.1 \\
\hline
\end{tabular}


Table 2. Cont

\begin{tabular}{cccc}
\hline RI $^{\text {calc }}$ & RI $^{\text {lit }}$ & Compound & \% \\
\hline 1243 & 1243 & Carvone & 0.2 \\
1246 & 1248 & Car-3-en-2-one & 0.4 \\
1248 & 1247 & Carvotanacetone & 0.2 \\
1253 & 1252 & Piperitone & 0.1 \\
1264 & 1268 & 3,5-Dimethoxytoluene & 0.2 \\
1277 & 1275 & Phellandranal & 0.3 \\
1290 & 1290 & Thymol & 0.2 \\
1296 & 1299 & Carvacrol & 0.3 \\
1419 & 1419 & $\beta$-Caryophyllene & 0.1 \\
1433 & 1434 & $\alpha-t r a n s-B e r g a m o t e n e$ & 0.9 \\
1581 & 1583 & Caryophyllene oxide & 0.2 \\
& & Total identified & $99.6 \%$ \\
\hline
\end{tabular}

$\mathrm{RI}^{\text {calc }}=\overline{\text { Retention indices calculated in reference to a homologous series of } n \text {-alkanes on a ZB-5MS }}$ column . $\mathrm{RI}^{\mathrm{lit}}=$ Retention indices from the literature [30].

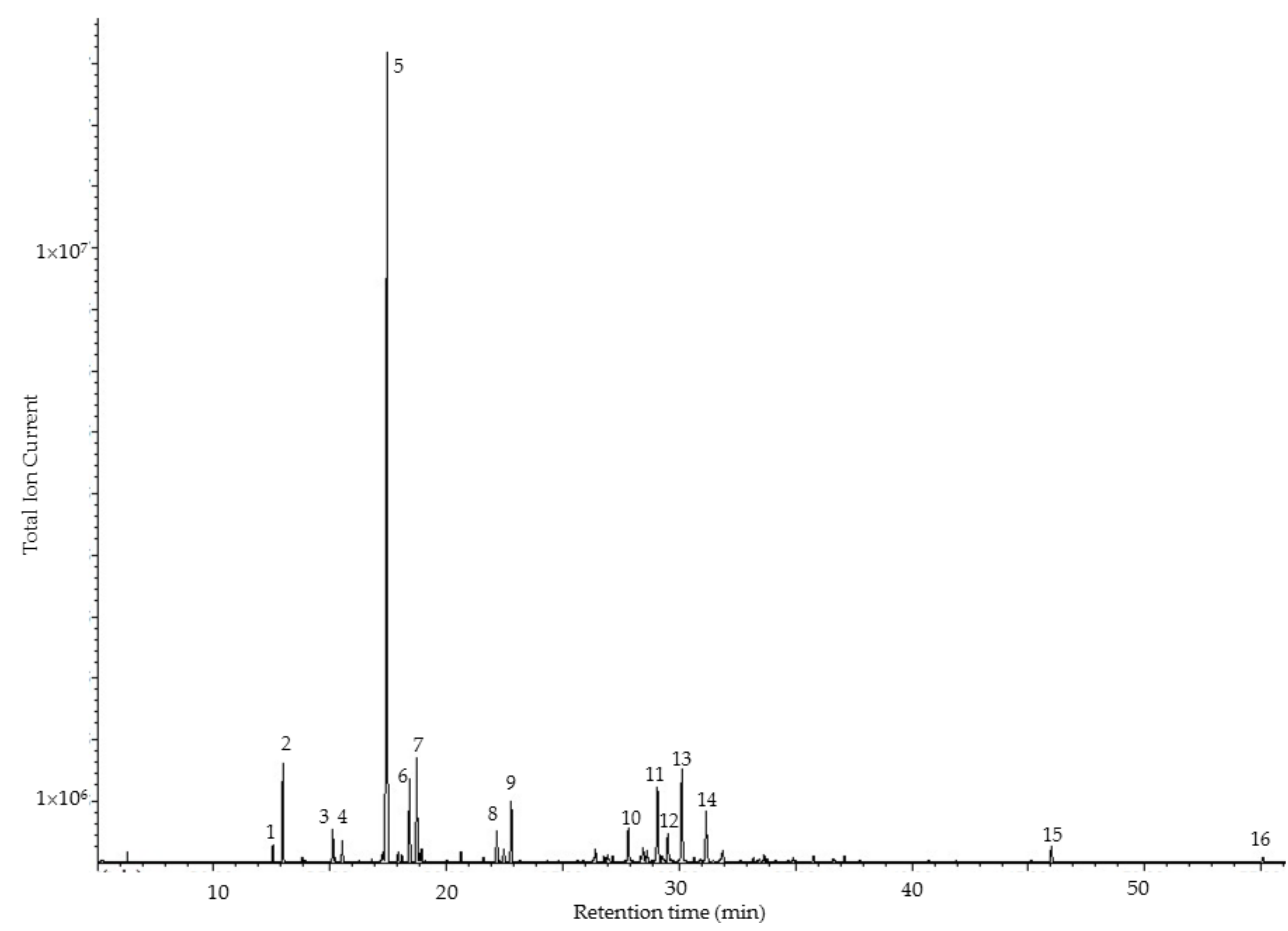

Figure 1. Gas chromatogram of the oleoresin essential oil of Protium amazonicum from Ecuador. 1, $\alpha$-thujene; 2, $\alpha$-pinene; 3, 3,7,7-trimethyl-1,3,5-cycloheptatriene; $4, \beta$-pinene; $5, \delta$-3-carene; 6 , $p$-cymene; 7, limonene; 8, $m$-cymenene; 9, $p$-cymenene; 10, $\alpha$-phellandren-8-ol; 11, $m$-cymen-8-ol; $12, p$-cymen-8-ol; 13, $\alpha$-terpineol; 14, 4-methyleneisophorone; 15, $\alpha$-trans-bergamotene; 16 , caryophyllene oxide.

\subsection{Enantiomeric Distribution}

Chiral GC-MS analysis was performed to evaluate the enantiomeric distribution of the monoterpenes present in P. amazonicum essential oil (see Table 3 and Figure 2). The levorotatory (-)-enantiomer of $\delta$-3-carene was found to be the exclusive stereoisomer while the (-)-enantiomers of $\alpha$-pinene, $\beta$-pinene, and sabinene predominated over the (+)-isomers. The (+)-enantiomers of limonene and $\alpha$-terpineol, on the other hand, were dominant. The hexane root extract of Angelica archangelica showed predominantly $(+)-\delta-3$-carene, but the (-)-enantiomer was detected [36]. Only the (+)-enantiomer of $\delta$-3-carene was detected in Pinus sylvestris (Pinaceae) essential oils, while (-)-limonene predominated [37]. The (+)-enantiomer of limonene is the more common, especially in Citrus (Rutaceae) essential oils [38-42]. 
Micromeria fruticosa (Lamiaceae) essential oil showed exclusively $(+)$ - $\alpha$-terpineol while $(-)$ - $\alpha$-terpineol was found in Laurus nobilis (Lauraceae) essential oil [43]. Analysis of the essential oil from the unripe fruits of Pistacia vera showed a predominance of $(+)$ - $\alpha$-pinene, (+)-limonene, $(+)-\beta$-pinene, and exclusively $(-)$ - $\alpha$-terpineol [44]. Although $\delta$-3-carene was relatively abundant in this oil (2.7\%), the enantiomeric distribution was unfortunately not reported. The oleoresin of Boswellia carterii (Burseraceae) from Ethiopia was composed of $(+)$ - $\alpha$-thujene, $(-)$ - $\alpha$-pinene, and (-)-limonene, but the enantiomeric distribution of $\delta$-3-carene was not determined [45]. In contrast, B. carterii resin oil from Somalia showed (-)- $\alpha$-thujene, $(-)$ - $\alpha$-pinene, and (-)-limonene predominating, while $B$. sacra resin oil from Oman had (+)- $\alpha$-thujene, (+)- $\alpha$-pinene, (+)- $\beta$-pinene, and (-)-limonene predominating [46].

Table 3. Enantiomeric excess (ee) and distribution (ed) of monoterpenoids in the resin oil of Protium amazonicum.

\begin{tabular}{cccc}
\hline Compounds & Relative $\%$ & ee $(\%)$ & ed $[(+)$ to $(-)](\%)$ \\
\hline$\alpha$-Thujene & 0.7 & 45.6 & 27.2 to 72.8 \\
$\alpha$-Pinene & 4.0 & 41.8 & 29.1 to 70.9 \\
$\beta$-Pinene & 1.0 & 45.6 & 27.2 to 72.8 \\
$\delta$-3-Carene & 47.9 & 100 & 0 to 100 \\
Limonene & 5.1 & 68.0 & 84.0 to 16.0 \\
$\alpha$-Terpineol & 5.5 & 79.6 & 89.8 to 10.2 \\
\hline
\end{tabular}

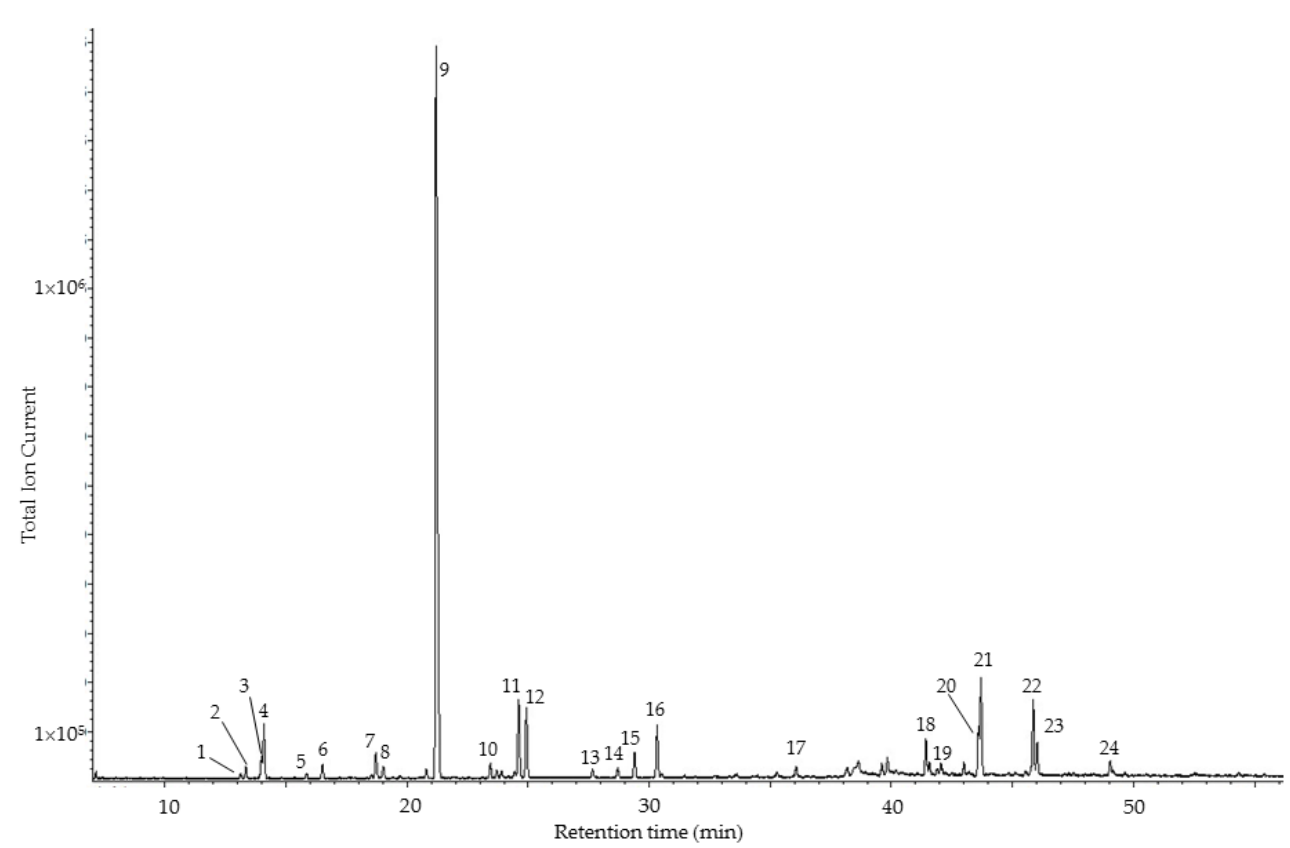

Figure 2. Chiral gas chromatogram of the oleoresin essential oil of Protium amazonicum. 1, (+)- $\alpha$-thujene; 2, (-)- $\alpha$-thujene; 3, (+)- $\alpha$-pinene; 4, (-)- $\alpha$-pinene; $5,(+)-\beta$-pinene; $6,(-)$ - $\beta$-pinene; 7, 3,7,7-trimethyl-1,3,5-cycloheptatriene; 8, 1,8-cineole; 9, (-)- $\delta$-3-carene; 10, (-)-limonene; 11, (+)-limonene; 12, $p$-cymene; 13, $\alpha$-terpinolene; 14, $\gamma$-terpinene; 15, $m$-cymenene; $16, p$-cymenene; 17 , camphor; 18, $\alpha$-phellandren-8-ol; $19,(-)$ - $\alpha$-terpineol; 20, eucarvone; $21,(+)$ - $\alpha$-terpineol; 22 , m-cymen-8-ol; 23, p-cymen-8-ol; 24, $\alpha$-trans-bergamotene.

\subsection{Antifungal Activity}

The oleoresin essential oil of P. amazonicum demonstrated antifungal activity against C. albicans, C. neoformans, and A. niger. C. neoformans was most potently inhibited with a promising MIC of $156 \mu \mathrm{g} / \mathrm{mL}$. Inhibition of C. albicans $(\mathrm{MIC}=313 \mu \mathrm{g} / \mathrm{mL})$ was also rather promising whereas inhibition of $A$. niger was relatively weak $(\mathrm{MIC}=1250 \mu \mathrm{g} / \mathrm{mL})$. The major component in P. amazonicum oil, 
8-3-carene, has shown antifungal activity against several fungi, including C. albicans [47]. In addition, minor monoterpenoid components in the oil, $\alpha$-pinene [48], limonene [49], and $\alpha$-terpineol [50], have also shown antifungal activities.

The antifungal mechanisms of activity of monoterpenoids are poorly understood. It has been suggested that these hydrophobic compounds disrupt the cytoplasmic membranes or membrane proteins of fungal cells, leading to cytoplasmic leakage, cell lysis, and death [51]. Chirality of monoterpenoids, therefore, may not play a critical role in antimicrobial activity. Nevertheless, Kusumoto and co-workers have shown that $(+)-\alpha$-pinene showed significantly better antifungal activity against Heterobasidion parviporum than (-)- $\alpha$-pinene [52]. Likewise, Filipowicz et al. showed (-)- $\beta$-pinene to be slightly more active than (+)- $\beta$-pinene against Candida albicans [53], and Omran and co-workers found that (-)-limonene had better antifungal activity than (+)-limonene [54]. $(+)-\delta-3$-Carene has shown antifungal activity against several fungal strains [47], but there are apparently no reports on antifungal activity of $(-)-\delta-3$-carene, which is not commercially available. Overall, these findings indicate that $P$. amazonicum resin oil has promising potential for further antifungal consideration, in particular against $C$. neoformans and potentially other yeast-like fungi.

\section{Conclusions}

This is the first reported chemical analysis of the oleoresin essential oil of Protium amazonicum. The P. amazonicum resin oil collected in Ecuador was dominated by (-)- $\delta-3$-carene and is therefore, an excellent source of this enantiomer. The abundance of this compound, along with other monoterpenoids, likely account for the observed antifungal activity of the oil. The activity against Cryptococcus neoformans and Candida albicans indicates promise against these opportunistic fungal pathogens. Additional research into this tree species and other Protium species, their chemistry and their biological activities, is needed.

Acknowledgments: The authors thank Erin McClelland of Middle Tennessee State University for the providing C. neoformans cells.

Author Contributions: P.S. conceived and designed the experiments; R.P.V. identified the plant and collected the oleoresin; P.S. and C.N.P. carried out the experiments; P.S., R.L.M., and W.N.S. analyzed the data; P.S. and R.L.M. contributed reagents/materials/analysis tools; P.S. and W.N.S. wrote the paper.

Conflicts of Interest: The authors declare no conflict of interest.

\section{References}

1. Mabberley, D.J. Mabberley's Plant-Book, 3rd ed.; Cambridge University Press: Cambridge, UK, 2008.

2. Rüdiger, A.L.; Siani, A.C.; Junior, V.F.V. The chemistry and pharmacology of the South America genus Protium Burm. f. (Burseracea). Pharmacogn. Rev. 2007, 1, 93-104.

3. Murthy, K.S.R.; Reddy, M.C.; Rani, S.S.; Pullaiah, T. Bioactive principles and biological properties of essential oils of Burseraceae: A review. J. Pharmacogn. Phytochem. 2016, 5, 247-258.

4. Stacey, R.J.; Cartwright, C.R.; McEwan, C. Chemical characterization of ancient Mesoamerican "copal" resins: Preliminary results. Archaeometry 2006, 48, 323-340. [CrossRef]

5. Siani, A.C.; Moraes, R.; Junior, V.F.V. Toward establishing the productive chain for triterpene-based Amazonian oleoresins as valuable non-timber forest products. Open J. For. 2017, 7, 188-208. [CrossRef]

6. Siani, A.C.; Ramos, M.F.S.; Menezes-de-Lima, O.; Ribeiro-dos-Santos, R.; Fernandez-Ferreira, E.; Soares, R.O.A.; Rosas, E.C.; Susunaga, G.S.; Guimarães, A.C.; Zoghbi, M.G.B.; et al. Evaluation of anti-inflammatory-related activity of essential oils from the leaves and resin of species of Protium. J. Ethnopharmacol. 1999, 66, 57-69. [CrossRef]

7. Amaral, M.P.M.; Braga, F.A.V.; Passos, F.F.B.; Almeida, F.R.C.; Oliveira, R.C.M.; Carvalho, A.A.; Chaves, M.H.; Oliveira, F.A. Additional evidence for the anti-inflammatory properties of the essential oil of Protium heptaphyllum resin in mice and rat. Latin Am. J. Pharm. 2009, 28, 775-782. 
8. Lima, F.V.; Malheiros, A.; Otuki, M.F.; Calixto, J.B.; Yunes, R.A.; Filho, V.C.; Monache, F.D. Three new triterpenes from the resinous bark of Protium kleinii and their antinociceptive activity. J. Braz. Chem. Soc. 2005, 16, 578-582. [CrossRef]

9. Rao, V.S.; Maia, J.L.; Oliveira, F.A.; Lemos, T.L.G.; Chaves, M.H.; Santos, F.A. Composition and antinociceptive activity of the essential oil from Protium heptaphyllum resin. Nat. Prod. Commun. 2007, 2, 1199-1202.

10. Siani, A.C.; Ramos, M.F.S.; da Monteiro, S.S.; Ribeiro-dos-Santos, R.; Soares, R.O.A. Essential oils of the oleoresins from Protium heptaphyllum growing in the Brazilian southeastern and their cytotoxicity to neoplastic cell lines. J. Essent. Oil Bear. Plants 2011, 14, 373-378. [CrossRef]

11. Oliveira, F.A.; Vieira-Júnior, G.M.; Chaves, M.H.; Almeida, F.R.C.; Florêncio, M.G.; Lima, R.C.P.; Silva, R.M.; Santos, F.A.; Rao, V.S.N. Gastroprotective and anti-inflammatory effects of resin from Protium heptaphyllum in mice and rats. Pharmacol. Res. 2004, 49, 105-111. [CrossRef] [PubMed]

12. Araujo, D.A.O.V.; Takayama, C.; De-Faria, F.M.; Socca, E.A.R.; Dunder, R.J.; Manzo, L.P.; Luiz-Ferreira, A.; Souza-Brito, A.R.M. Gastroprotective effects of essential oil from Protium heptaphyllum on experimental gastric ulcer models in rats. Braz. J. Pharmacogn. 2011, 21, 721-729. [CrossRef]

13. Milliken, W.; Albert, B. The use of medicinal plants by the Yanomami Indians of Brazil, Part II. Econ. Bot. 1997, 51, 264-278. [CrossRef]

14. Siani, A.C.; Nakamura, M.J.; Tappin, M.R.R.; Monteiro, S.S.; Guimarães, A.C.; Ramos, M.F.S. Chemical composition of South American Burseraceae non-volatile oleoresins and preliminary solubility assessment of their commercial blend. Phytochem. Anal. 2012, 23, 529-539. [CrossRef] [PubMed]

15. Da Silva, E.R.; de Oliveira, D.R.; de Melo, M.F.F.; Bizzo, H.R.; Leitão, S.G. Report on the Malungo expedition to the Erepecuru river, Oriximiná, Brazil. Part I: Is there a difference between black and white breu? Rev. Bras. Farmacogn. 2016, 26, 647-656. [CrossRef]

16. Pontes, W.J.T.; de Oliveira, J.C.S.; da Camara, C.A.G.; Lopes, A.C.H.R.; Júnior, M.G.C.G.; de Oliveira, J.V.; Schwartz, M.O.E. Composition and acaricidal activity of the resin's essential oil of Protium bahianum Daly against two spotted spider mite (Tetranychus urticae). J. Essent. Oil Res. 2007, 19, 379-383. [CrossRef]

17. De Carvalho, L.E.; da Pinto, D.S.; Magalhães, L.A.M.; da Lima, M.P.; Marques, M.O.M.; Facanali, R. Chemical constituents of essential oil of Protium decandrum (Burseraceae) from western Amazon. J. Essent. Oil Bear. Plants 2010, 13, 181-184. [CrossRef]

18. Bandeira, P.N.; Fonseca, A.M.; Costa, S.M.O.; Lins, M.U.D.S.; Pessoa, O.D.L.; Monte, F.J.Q.; Nogueira, N.A.P.; Lemos, T.L.G. Antimicrobial and antioxidant activities of the essential oil of resin of Protium heptaphyllum. Nat. Prod. Commun. 2006, 1, 117-120.

19. De Lima, E.M.; Cazelli, D.S.P.; Pinto, F.E.; Mazuco, R.A.; Kalil, I.C.; Lenz, D.; Scherer, R.; de Andrade, T.U.; Endringer, D.C. Essential oil from the resin of Protium heptaphyllum: Chemical composition, cytotoxicity, antimicrobial activity, and antimutagenicity. Pharmacogn. Mag. 2016, 12, S42-S46. [PubMed]

20. Albino, R.C.; Oliveira, P.C.; Prosdocimi, F.; da Silva, O.F.; Bizzo, H.R.; Gama, P.E.; Sakuragui, M.; Furtado, C.; de Oliveira, D.R. Oxidation of monoterpenes in Protium heptaphyllum oleoresins. Phytochemistry 2017, 136, 141-146. [CrossRef] [PubMed]

21. Pinto, F.E.; Heringer, O.A.; Silva, M.A.; Uggere, T.; Ribeiro, J.S.; Lenz, D.; Campos, F.; Lessa, R.; Endringer, D.C. Stability and disinfecting proprieties of the toothbrush rinse of the essential oil of Protium heptaphyllum. Afr. J. Pharm. Pharmacol. 2015, 9, 173-181.

22. Mobin, M.; de Lima, S.G.; Almeida, L.T.G.; Silva Filho, J.C.; Rocha, M.S.; Oliveira, A.P.; Mendes, M.B.; Carvalho, F.A.A.; Melhem, M.S.C.; Costa, J.G.M. Gas chromatography-triple quadrupole mass spectrometry analysis and vasorelaxant effect of essential oil from Protium heptaphyllum (Aubl.) March. BioMed Res. Int. 2017, 2017, 1928171. [CrossRef]

23. Siani, A.C.; Ramos, M.F.S.; Guimarães, A.C.; Susunaga, G.S.; Zoghbi, M.G.B. Volatile constituents from oleoresin of Protium heptaphyllum (Aubl.) March. J. Essent. Oil Res. 1999, 11, 72-74. [CrossRef]

24. Bandeira, P.N.; Machado, M.I.L.; Cavalcanti, F.S.; Lemos, T.L.G. Essential oil composition of leaves, fruits and resin of Protium heptaphyllum (Aubl.) March. J. Essent. Oil Res. 2001, 13, 33-34. [CrossRef]

25. Da Silva, E.R.; Oliveira, D.R.; Leitão, S.G.; Assis, I.M.; Veiga-Junior, V.F.; Lourenço, M.C.; Alviano, D.S.; Alviano, C.S.; Bizzo, H.R. Essential oils of Protium spp. samples from Amazonian popular markets: Chemical composition, physicochemical parameters and antimicrobial activity. J. Essent. Oil Res. 2013, 25, 171-178. [CrossRef] 
26. Marques, D.D.; Sartori, R.A.; Lemos, T.L.G.; Machado, L.L.; de Souza, J.S.N.; Monte, F.J.Q. Chemical composition of the essential oils from two subspecies of Protium heptaphyllum. Acta Amazon. 2010, 40, 227-230. [CrossRef]

27. Siani, A.C.; Garrido, I.S.; Monteiro, S.S.; Carvalho, E.S.; Ramos, M.F.S. Protium icicariba as a source of volatile essences. Biochem. Syst. Ecol. 2004, 32, 477-489. [CrossRef]

28. Suárez, A.I.; Compagnone, R.S.; Acosta, D.; Vásquez, L.; Diaz, B.; Canelón, D.J. Chemical composition and antimicrobial activity of the essential oil from oleoresin of Protium neglectum S. J. Essent. Oil Bear. Plants 2007, 10, 70-75. [CrossRef]

29. Satyal, P.; Setzer, W.N. Chemical composition of Cryptomeria japonica leaf oil from Nepal. Am. J. Essent. Oils Nat. Prod. 2015, 3, 7-10.

30. Adams, R.P. Identification of Essential Oil Components by Gas Chromatography/Mass Spectrometry, 4th ed.; Allured Publishing: Carol Stream, IL, USA, 2007.

31. Surapuram, V.; Setzer, W.N.; McFeeters, R.L.; McFeeters, H. Antifungal activity of plant extracts against Aspergillus niger and Rhizopus stolonifer. Nat. Prod. Commun. 2014, 9, 1603-1605. [PubMed]

32. Satyal, P.; Murray, B.L.; McFeeters, R.L.; Setzer, W.N. Essential oil characterization of Thymus vulgaris from various geographical locations. Foods 2016, 5, 70. [CrossRef] [PubMed]

33. Hausen, B.M.; Reichling, J.; Harkenthal, M. Degradation products of monoterpenes are the sensitizing agents in tea tree oil. Am. J. Contact Dermat. 1999, 10, 68-77. [CrossRef]

34. Sawamura, M.; Son, U.-S.; Choi, H.-S.; Kim, M.-S.L.; Phi, N.T.L.; Fears, M.; Kumagai, C. Compositional changes in commercial lemon essential oil for aromatherapy. Int. J. Aromather. 2004, 14, 27-63. [CrossRef]

35. Turek, C.; Stintzing, F.C. Impact of different storage conditions on the quality of selected essential oils. Food Res. Int. 2012, 46, 341-353. [CrossRef]

36. Holm, Y.; Vuorela, P.; Hiltunen, R. Enantiomeric composition of monoterpene hydrocarbons in $n$-hexane extracts of Angelica archangelica L. roots and seeds. Flavour Fragr. J. 1997, 12, 397-400. [CrossRef]

37. Sjödin, K.; Persson, M.; Borg-Karlson, A.-K.; Norin, T. Enantiomeric compositions of monoterpene hydrocarbons in different tissues of four individuals of Pinus sylvestris. Phytochemistry 1996, 41, 439-445. [CrossRef]

38. Mosandl, A.; Hener, U.; Kreis, P.; Schmarr, H.-G. Enantiomeric distribution of $\alpha$-pinene, $\beta$-pinene and limonene in essential oils and extracts. Part 1. Rutaceae and Gramineae. Flavour Fragr. J. 1990, 5, 193-199. [CrossRef]

39. Dugo, G.; d'Alcontres, I.S.; Donato, M.G.; Dugo, P. On the genuineness of citrus essential oils. Part XXXVI. Detection of added reconstituted lemon oil in genuine cold-pressed lemon essential oil by high resolution gas chromatography with chiral capillary columns. J. Essent. Oil Res. 1993, 5, 21-26. [CrossRef]

40. Eleni, M.; Antonios, M.; George, K.; Alexios-Leandros, S.; Prokopios, M. High quality bergamot oil from Greece: Chemical analysis using chiral gas chromatography and larvicidal activity against the West Nile virus vector. Molecules 2009, 14, 839-849. [CrossRef] [PubMed]

41. Sciarrone, D.; Schipilliti, L.; Ragonese, C.; Tranchida, P.Q.; Dugo, P.; Dugo, G.; Mondello, L. Thorough evaluation of the validity of conventional enantio-gas chromatography in the analysis of volatile chiral compounds in mandarin essential oil: A comparative investigation with multidimensional gas chromatography. J. Chromatogr. A 2010, 1217, 1101-1105. [CrossRef] [PubMed]

42. Delort, E.; Jaquier, A.; Decorzant, E.; Chapuis, C.; Casilli, A.; Frérot, E. Comparative analysis of three Australian finger lime (Citrus australasica) cultivars: Identification of unique citrus chemotypes and new volatile molecules. Phytochemistry 2015, 109, 111-124. [CrossRef] [PubMed]

43. Ravid, U.; Putievsky, E.; Katzir, I. Determination of the enantiomeric composition of $\alpha$-terpineol in essential oils. Flavour Fragr. J. 1995, 10, 281-284. [CrossRef]

44. Tsokou, A.; Georgopoulou, K.; Melliou, E.; Magiatis, P.; Tsitsa, E. Composition and enantiomeric analysis of the essential oil of the fruits and the leaves of Pistacia vera from Greece. Molecules 2007, 12, 1233-1239. [CrossRef] [PubMed]

45. Basar, S.; Koch, A.; König, W.A. A verticillane-type diterpene from Boswellia carterii essential oil. Flavour Fragr. J. 2001, 16, 315-318. [CrossRef] 
46. Woolley, C.L.; Suhail, M.M.; Smith, B.L.; Boren, K.E.; Taylor, L.C.; Schreuder, M.F.; Chai, J.K.; Casabianca, H.; Haq, S.; Lin, H.K.; et al. Chemical differentiation of Boswellia sacra and Boswellia carterii essential oils by gas chromatography and chiral gas chromatography-mass spectrometry. J. Chromatogr. A 2012, 1261, 158-163. [CrossRef] [PubMed]

47. Cavaleiro, C.; Pinto, E.; Gonçalves, M.J.; Salgueiro, L. Antifungal activity of Juniperus essential oils against dermatophyte, Aspergillus and Candida strains. J. Appl. Microbiol. 2006, 100, 1333-1338. [CrossRef] [PubMed]

48. Schmidt, J.M.; Noletto, J.A.; Vogler, B.; Setzer, W.N. Abaco bush medicine: Chemical composition of the essential oils of four aromatic medicinal plants from Abaco Island, Bahamas. J. Herbs Spices Med. Plants 2006, 12, 43-65. [CrossRef]

49. Marei, G.I.K.; Rasoul, M.A.A.; Abdelgaleil, S.A.M. Comparative antifungal activities and biochemical effects of monoterpenes on plant pathogenic fungi. Pestic. Biochem. Physiol. 2012, 103, 56-61. [CrossRef]

50. Hammer, K.A.; Carson, C.F.; Riley, T.V. Antifungal activity of the components of Melaleuca alternifolia (tea tree) oil. J. Appl. Microbiol. 2003, 95, 853-860. [CrossRef] [PubMed]

51. Jing, L.; Lei, Z.; Li, L.; Xie, R.; Xi, W.; Guan, Y.; Sumner, L.W.; Zhou, Z. Antifungal activity of Citrus essential oils. J. Agric. Food Chem. 2014, 62, 3011-3033. [CrossRef] [PubMed]

52. Kusumoto, N.; Zhao, T.; Swedjemark, G.; Ashitani, T.; Takahashi, K.; Borg-Karlson, A.-K. Antifungal properties of terpenoids in Picea abies against Heterobasidion parviporum. For. Pathol. 2014, 44, 353-361. [CrossRef]

53. Filipowicz, N.; Kaminski, M.; Kurlenda, J.; Asztemborska, M.; Ochocka, J.R. Antibacterial and antifungal activity of juniper berry oil and its selected components. Phytother. Res. 2003, 17, 227-231. [CrossRef] [PubMed]

54. Omran, S.M.; Moodi, M.A.; Amiri, S.M.B.N.A.; Mosavi, S.J.; Saeed, S.A.M.G.M.; Shiade, S.M.J.; Kheradi, E.; Salehi, M. The effects of limonene and orange peel extracts on some spoilage fungi. Int. J. Mol. Clin. Microbiol. 2011, 1, 82-86.

(C) 2017 by the authors. Licensee MDPI, Basel, Switzerland. This article is an open access article distributed under the terms and conditions of the Creative Commons Attribution (CC BY) license (http:/ / creativecommons.org/licenses/by/4.0/). 